\title{
Alzheimer Amyloid Protein Precursor in the Rat Hippocampus: Transport and Processing through the Perforant Path
}

\author{
Joseph D. Buxbaum, ${ }^{1}$ Gopal Thinakaran, ${ }^{2}$ Vassilis Koliatsos, ${ }^{2,4}$ James O'Callahan, ${ }^{1,5}$ Hilda H. Slunt, ${ }^{2}$ \\ Donald L. Price, ${ }^{2-4}$ and Sangram S. Sisodia ${ }^{6}$ \\ 1 Laboratory of Molecular Neuropsychiatry, Department of Psychiatry, Mount Sinai School of Medicine, New York, New \\ York 10029, Departments of ${ }^{2}$ Pathology, ${ }^{3}$ Neurology, and ${ }^{4}$ Neuroscience, The Johns Hopkins University School of \\ Medicine, Baltimore, Maryland 21205, ${ }^{5}$ Center for Disease Control and Prevention, National Institute of Occupational \\ Safety and Health, Morgantown, West Virginia 26505, and 'Department of Pharmacological and Physiological Sciences, \\ The University of Chicago, Chicago, Illinois 60637
}

Amyloid deposition is a neuropathological hallmark of Alzheimer's disease. The principal component of amyloid deposits is $\beta$ amyloid peptide $(\mathrm{A} \beta)$, a peptide derived by proteolytic processing of the amyloid precursor protein (APP). APP is axonally transported by the fast anterograde component. Several studies have indicated that $A \beta$ deposits occur in proximity to neuritic and synaptic profiles. Taken together, these latter observations have suggested that APP, axonally transported to nerve terminals, may be processed to $A \beta$ at those sites. To examine the fate of APP in the CNS, we injected $\left[{ }^{35}\right.$ S]methionine into the rat entorhinal cortex and examined the trafficking and processing of de novo synthesized APP in the perforant pathway and at presynaptic sites in the hippocampal formation. We report that both full-length and processed APP accumulate at presynaptic terminals of entorhinal neurons. Finally, we demonstrate that at these synaptic sites, C-terminal fragments of APP containing the entire $A \beta$ domain accumulate, suggesting that these species may represent the penultimate precursors of synaptic $A \beta$.

Key words: Alzheimer's disease; axonal transport; $A \beta$; amyloid precursor protein; entorhinal cortex; hippocampus
Extracellular deposits of $\beta$ amyloid peptides (A $\beta s)$ are an invariant, defining neuropathological hallmark of Alzheimer's disease (Glenner and Wong, 1984). A $\beta$ is derived by proteolysis of larger transmembrane proteins, termed amyloid precursor proteins (APP). APP isoforms are encoded by several alternatively spliced transcripts (Kang et al., 1987; Kitaguchi et al., 1988; Ponte et al., 1988; Tanzi et al., 1988; Golde et al., 1990; König et al., 1992). In rodents, neurons express the APP-695 isoform ( $\left.\mathrm{APP}_{695}\right)$, whereas non-neuronal cells express APP-751 $\left(\mathrm{APP}_{751}\right)$ and APP-770 $\left(\mathrm{APP}_{770}\right)$, isoforms that contain a domain that is structurally and functionally homologous to Kunitz protease inhibitors (KPI) (Sisodia et al., 1993). APP is subject to endoproteolytic cleavage within the $\mathrm{A} \beta$ sequence by " $\alpha$-secretase," a process that results in secretion of a large, C-terminal-truncated derivative $\left(\mathrm{APP}_{\mathrm{s}}\right)$ into the extracellular space (Weidemann et al., 1989; for review, see Selkoe, 1996). This processing pathway precludes amyloid formation. However, a fraction of APP is subject to endoproteolysis by $\beta$-secretase activities (at the $\mathrm{N}$ terminal of the $\mathrm{A} \beta$ sequence) to generate a $\mathrm{C}$-terminal, membrane-bound fragment (CTF) that is subsequently cleaved within the transmembrane domain by

\footnotetext{
Received May 27, 1998; revised Sept. 1, 1998; accepted Sept. 4, 1998.

This work was supported by National Institutes of Health Grants AG 05146 and NS 20471 (S.S.S. and D.L.P.) and AG14996 (J.D.B.), by the Adler Foundation (S.S.S. and G.T.), and by the American Health Assistance Foundation (J.D.B.). We thank Drs. G. Perry (Case Western Reserve University, Cleveland, $\mathrm{OH}$ ) and Edward Koo (University of California, San Diego, CA) for generously providing RGP3 and CT15 antiserum, respectively. We also thank Dr. Brad Hyman (Harvard Medical School) for initially suggesting these experiments and for subsequent discussions.

Correspondence should be addressed to Dr. Sangram S. Sisodia, Professor of Pharmacological and Physiological Sciences, The University of Chicago, 947 East 58th Street Abbott 316, Chicago, IL 60637.

Drs. J.D. Buxbaum and G. Thinakaran contributed equally to this study. Copyright (C) 1998 Society for Neuroscience $\quad 0270-6474 / 98 / 189629-09 \$ 05.00 / 0$
}

$\gamma$-secretase activities to generate $\mathrm{A} \beta$ peptides (for review, see Selkoe, 1996).

Although the metabolism of APP in cultured cells has been extensively investigated, the fate of APP synthesized in terminally differentiated neurons in the adult CNS is primarily unknown. However, some studies of APP metabolism have been performed in in vivo settings, and several notable findings have emerged; APP undergoes fast axonal transport in dorsal root and retinal ganglion neurons (Koo et al., 1990; Morin et al., 1993; Sisodia et al., 1993), and APP is transported to presynaptic terminals and is present in rab5-containing multilamellar vesicles (Ikin et al., 1996; Marquez-Sterling et al., 1997) and in clathrincoated vesicles (Nordstedt et al., 1993; Marquez-Sterling et al., 1997), organelles that are likely to be involved in endocytosis. Together with the demonstration that endocytosis plays an important role in $\mathrm{A} \beta$ formation in cultured cells (Koo and Squazzo, 1994), the in vivo data suggest that APP processing might occur in the presynaptic terminals of differentiated central neurons. To address this issue, we injected $\left[{ }^{35} \mathrm{~S}\right]$ methionine into the rat entorhinal cortex and examined the trafficking and processing of de novo synthesized APP within the entorhinal cortex and the terminal fields of entorhinal neurons. We demonstrate that $\left[{ }^{35} \mathrm{~S}\right]$ methionine-labeled APP is transported via the perforant pathway to the presynaptic terminals of synapses in the dentate gyrus and that both soluble C-terminal-truncated APP forms and CTFs of APP harboring the entire $\mathrm{A} \beta$ sequence accumulate at these presynaptic sites.

\section{MATERIALS AND METHODS}

Reverse transcriptase-PCR. Total RNA was purified from dissected entorhinal cortex after homogenization of the tissue in guanidinium thiocyanate and centrifugation of the lysate through a $\mathrm{CsCl}$ cushion. For reverse transcription (RT), $2 \mu \mathrm{g}$ of total RNA and $50 \mathrm{pmol}$ of antisense 
primer (AS1219, ctctctcggtgcttggcttc) were heated to $65^{\circ} \mathrm{C}$, cooled, and then incubated with reverse transcriptase and deoxynucleotide triphosphates at $42^{\circ} \mathrm{C}$. The reaction was terminated by heating to $95^{\circ} \mathrm{C}$ and diluting with PCR buffer (50 mM KCl, $10 \mathrm{~mm}$ Tris $\mathrm{HCl}, \mathrm{pH} 8.3,1.5 \mathrm{~mm}$ $\mathrm{MgCl}_{2}$, and $0.01 \%$ gelatin). The resulting mixture was divided into aliquots, and each aliquot was subjected to PCR with 25 pmol of sense primer (S640, cggacagcatcgattctgcg), 4 pmol of ${ }^{32} \mathrm{P}-5^{\prime}$ end-labeled S640, and 20 pmol of antisense primer (AS1219) in the presence of Taq DNA polymerase. The sense primer was end-labeled using T4 polynucleotide kinase and $\gamma^{32} \mathrm{P}$-labeled ATP. Individual reactions were terminated at 16 , 18,20 , or 22 cycles, and one quarter of each reaction was fractionated by electrophoresis on $2 \%$ agarose gels. Gels were stained with ethidium bromide $(\mathrm{EtBr})$ to visualize bands, whereas radioactive products were identified by exposure of the dried gel to x-ray film. The intensity of the autoradiographic signal was quantified using phosphorimaging technology (Molecular Dynamics, Sunnyvale, CA), and the logarithm of the signal was plotted as a function of cycle number.

Labeling of the perforant path. To radiolabel proteins undergoing axonal transport along the perforant path, we injected $0.5 \mu \mathrm{l}$ of $\left[{ }^{35} \mathrm{~S}\right] \mathrm{me}-$ thionine $(1 \mathrm{mCi} / \mu \mathrm{l}$ in $10 \mathrm{~mm}$ tricine $\cdot \mathrm{HCl}, \mathrm{pH} 7.4)$ into the entorhinal cortex of rats anesthetized with chlorpromazine $(3 \mathrm{mg} / \mathrm{kg}$, i.p.) followed 5 min later with ketamine $(100 \mathrm{mg} / \mathrm{kg}$, i.m.). The injections were performed with the aid of a stereotactic instrument (Kopf, Tujunga, CA) at the coordinates $-7.8 \mathrm{~mm}$ posterior to bregma, $5 \mathrm{~mm}$ lateral, and $0.8 \mathrm{~mm}$ above contact with bone. After infusion of the label over 5-10 min, transport was allowed to proceed for $6 \mathrm{hr}$, and the rats were then killed by decapitation. The entorhinal cortex and the hippocampal formation were removed for further analysis.

In some experiments, the dentate gyrus was dissected away from the dorsal hippocampus. For these experiments, $400-\mu \mathrm{m}$-thick transverse sections of dorsal hippocampus were prepared using a McIlwain Tissue Chopper (Brinkman Instruments, Westbury, NY). Each slice was transilluminated on a translucent glass stage of a dissecting microscope, and the dendate gyrus was dissected. When dissected in this manner, each sample would also include a small portion of sectors CA3 and CA4. Typically, samples dissected from five to six slices were pooled for each analysis and were immediately frozen on dry ice.

Immunoprecipitation from brain tissue. APP-related polypeptides were extracted by homogenization of brain tissue in immunoprecipitation buffer $(150 \mathrm{~mm} \mathrm{NaCl}, 50 \mathrm{~mm}$ Tris $\mathrm{HCl}$, pH 7.5, $5 \mathrm{~mm}$ EDTA, $0.5 \%$ NP-40, $0.5 \%$ sodium deoxycholate, $0.25 \%$ SDS, $50 \mu \mathrm{g} / \mathrm{ml}$ leupeptin, 10 $\mu \mathrm{g} / \mathrm{ml}$ aprotinin, and $0.25 \mathrm{~mm}$ phenylmethylsulfonyl fluoride) and by boiling for $5 \mathrm{~min}$, followed by centrifugation at $15,000 \times \mathrm{g}$ for $5 \mathrm{~min}$ to remove insoluble material. APP-related molecules were immunoprecipitated from the soluble fraction (Sisodia et al., 1990) with polyclonal antiserum RGP3 raised against a synthetic peptide corresponding to APP residues 45-62 (Perry et al., 1988; Sisodia et al., 1993) or with polyclonal antiserum CT15 raised against a synthetic peptide corresponding to the C-terminal 15 residues of APP (Sisodia et al., 1993; Zheng et al., 1995). Immunoprecipitates were fractionated by SDSPAGE using $6 \%$ Tris-glycine, $16 \%$ Tris-glycine, or $16 \%$ Tris-tricine gels and were visualized by autoradiography.

Analysis of phosphorylation state of APP C-terminal fragments. To assess the phosphorylation of APP C-terminal fragments, we prepared detergent extracts from entorhinal cortex or hippocampus, as described above, and subjected $500 \mathrm{mg}$ of detergent-soluble proteins to immunoprecipitation analysis with CT15 or $3134 \mathrm{~N}$, an antibody that specifically reacts with epitopes encompassing $\mathrm{A} \beta$ residues $5-12$. The antibody $3134 \mathrm{~N}$ was generated by affinity purification of the A $\beta 1-40$ peptidespecific antibody Ab3134 (Desdouits et al., 1996) on an immobilized A $\beta 1-13$ peptide column. Epitope mapping studies, using an immobilized overlapping peptide strategy, revealed that the recovered antibodies were reactive to epitopes between amino acids 5 and 12 of $\mathrm{A} \beta$. Immune complexes were captured with Protein A-agarose beads (Pierce, Rockford, IL), and bound antigens were digested in situ with 600 units of bacteriophage $\lambda$ phosphatase (New England Biolabs, Beverly, MA) for 1 $\mathrm{hr}$ at $37^{\circ} \mathrm{C}$ in a buffer containing $50 \mathrm{~mm}$ Tris- $\mathrm{HCl}, \mathrm{pH} 7.8,5 \mathrm{~mm}$ dithiothreitol, $2 \mathrm{mM} \mathrm{MgCl}_{2}$, and $100 \mathrm{mg} / \mathrm{ml} \mathrm{BSA}$. Antigen-antibody complexes were disrupted by boiling in Laemmli sample buffer, fractionated by SDS-PAGE on Tris-tricine gels, and subjected to Western blot analysis with CT15 antibody.

\section{RESULTS}

The hippocampal formation (Fig. 1) plays an important role in certain aspects of learning and declarative memory (Squire,

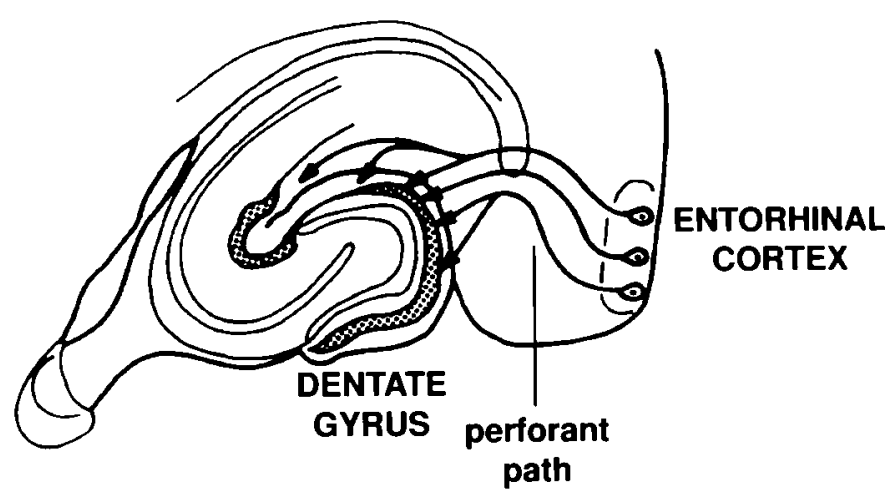

Figure 1. Elements of the perforant path. The perforant path originates in the entorhinal cortex, from which it "perforates" the hippocampal fissure before terminating in all parts of the hippocampus. A major target of the pathway is the granule cells of the dentate gyrus that in turn project to region CA3 via the mossy fiber axons.

1994); these neuropsychological parameters are profoundly diminished in Alzheimer's disease. The hippocampal formation is also a major site of Alzheimer's disease pathology, including extensive deposition of amyloid in senile plaques (Braak and Braak, 1994; Price et al., 1996). Thus, the processes that contribute to amyloidosis in the hippocampal formation are of great interest. A major afferent pathway to the hippocampal formation is the perforant path, in which neurons from layers II and III of the entorhinal cortex project through the hippocampal fissure, terminating in all parts of the hippocampus. A well-defined projection area of the perforant path is the granule cell layer of the dentate gyrus, in which the majority of synapses in the outer two-thirds of the dendritic fields of these cells receive their input from layer II/III of the entorhinal cortex. It is of interest to note that the entorhinal cortex is one of the most severely affected areas in Alzheimer's disease, with intraneuronal neurofibrillary changes occurring in this region at the earliest stages of the disease (Arnold et al., 1991; Braak and Braak, 1994; Price et al., 1996). We sought to examine the trafficking and processing of APP in the perforant path to clarify the fate of neuronally synthesized APP at synaptic sites.

\section{Cells of the entorhinal cortex express mRNA encoding APP isoforms lacking the KPI sequences}

To assess the relative levels of transcripts encoding $\mathrm{APP}_{695}$, $\mathrm{APP}_{751}$, and $\mathrm{APP}_{770}$ in the entorhinal cortex, we analyzed RNA prepared from dissected entorhinal cortex by RT-PCR using primers that bracket the KPI domain (Sisodia et al., 1993). Under these conditions, PCR gives rise to specific products of 350,518 , and 575 base pairs (bp) that represent mRNA encoding $\mathrm{APP}_{695}$, $\mathrm{APP}_{751}$, and $\mathrm{APP}_{770}$, respectively. PCR products were fractionated by electrophoresis in agarose gels and stained with $\mathrm{EtBr}$ to visualize the products (Fig. $2 A$, left). Although an $\sim 350 \mathrm{bp}$ product is visualized by EtBr staining in cycles 16-22 of the PCR, larger products of 518 and 575 bp are barely detectable. After exposure of the dried gel to x-ray film, the products derived from $\mathrm{APP}_{751}$ and $\mathrm{APP}_{770}$ are readily visualized as well (Fig. $2 A$, right). To establish that PCR was conducted in the linear range of amplification, we performed reactions for 16, 18, 20, and 22 cycles and quantified the radioactivity for each product by storage phosphorimaging (Fig. $2 B$ ). Equations for each line were derived by a least squares method, and the regression coefficient $\left(R^{2}\right)$ was calculated. The regression coefficient is essentially unity, support- 

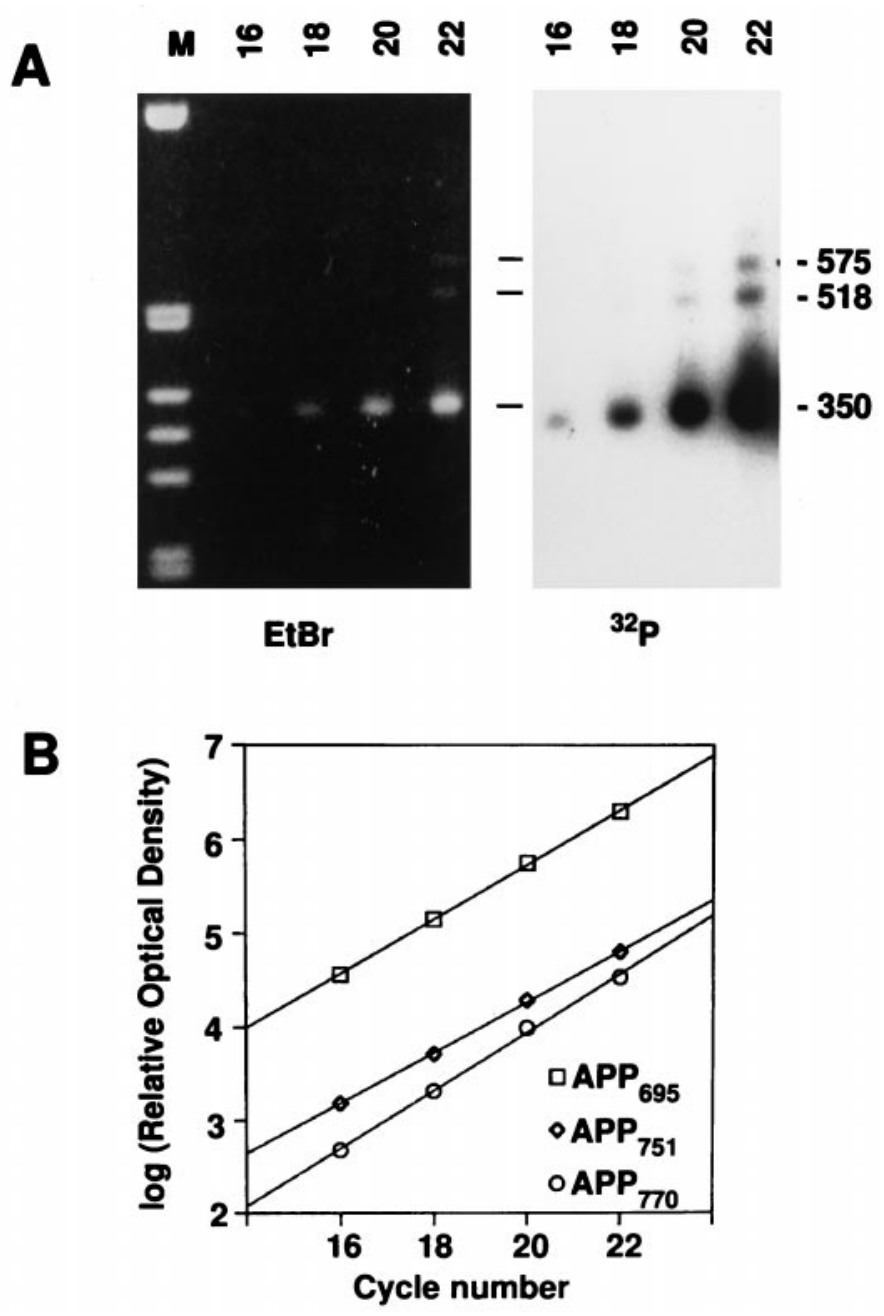

Figure 2. $\mathrm{APP}_{695}$ mRNA in enriched in the entorhinal cortex. For analysis of APP mRNA, RNA was reverse transcribed using antisense primer AS1219, and the reverse-transcribed products were incubated in a PCR with ${ }^{32} \mathrm{P}-5^{\prime}$ end-labeled sense primer. $A$, PCR analysis of APP mRNA. Amplified products generated after 16, 18, 20, or 22 cycles of the PCR procedure were fractionated by agarose electrophoresis and visualized by EtBr staining (left) and autoradiography (right). PCR products were generated from transcripts encoding $\mathrm{APP}_{695}$ (350 bp), $\mathrm{APP}_{751}(518$ $\mathrm{bp}$ ), and $\mathrm{APP}_{770}(575 \mathrm{bp}) M, 1 \mathrm{~kb}$ ladder (Life Technologies, Rockville, MD). B, Quantification of PCR analysis. Autoradiograms were subjected to quantitative densitometry, and the cycle number was plotted versus the $\log$ of the relative density. Regression analysis was performed for each product, and the equations (and regression coefficients) were determined as follows: $\mathrm{APP}_{695} y=0.290 x-0.062(1.000) ; \mathrm{APP}_{751} y=0.271 x-1.156$ (1.000); and $\mathrm{APP}_{770} y=0.312 x-2.297$ (0.998).

ing the linearity of amplification over this range. These data show that the mRNA encoding $\mathrm{APP}_{695}$ is expressed at $\sim 30$-fold the levels of transcripts that encode the KPI-containing isoforms, results that fully support earlier reports that concluded that $\mathrm{APP}_{695}$ mRNAs are the principal APP-encoding transcripts in adult rat brain (Neve et al., 1988; Ohyagi et al., 1990; Beyreuther and Masters, 1991; Sandbrink et al., 1994).

\section{APP is transported in the perforant pathway}

To analyze the in vivo transport of de novo synthesized APP in the perforant path, we injected $\left[{ }^{35} \mathrm{~S}\right]$ methionine into the rat entorhinal cortex. Six hours later, we immunoprecipitated labeled APP-related molecules from the entorhinal cortex and from the hippocampal formation. For immunoprecipitations, we used antibody RGP3, specific for N-terminal residues 45-62 (anti- $\left.\mathrm{NH}_{2}\right)$ of APP (Perry et al., 1988; Sisodia et al., 1993), and antibody CT15, specific for the C-terminal residues 681-695 of APP-695 (anti-COOH) (Sisodia et al., 1993; Zheng et al., 1995; von Koch et al., 1997). Full-length and C-terminal-truncated (soluble) APP are detected with RGP3, whereas full-length and C-terminal membrane-retained fragments of APP are detected with CT15; CT15 antibody specificity was established by showing that the antibody fails to detect APP-related polypeptides in extracts of tissues prepared from mice with inactivated APP alleles (Zheng et al., 1995). In the entorhinal cortex, CT15 precipitated three polypeptides of $\sim 100-120 \mathrm{kDa}$; only the two slower migrating species were also observed in immunoprecipitates from the hippocampal formation (Fig. $3 \mathrm{~A}$, left). Our interpretation of these results is that the $\sim 110-120 \mathrm{kDa}$ polypeptides detected in both the entorhinal cortex and the dentate gyrus are full-length, fully glycosylated forms of APP-695, whereas the $\sim 100 \mathrm{kDa}$ polypeptide detected uniquely in the entorhinal cortex represents fulllength, endoplasmic reticulum (ER) forms of APP-695 that are incompletely glycosylated. It is important to note that earlier studies have indicated that experimental lesions and degeneration of the CNS and PNS lead to upregulated expression of KPIcontaining APP isoforms; the principal cells in which KPI APP isoforms are induced are astrocytes or microglia (Tanzi et al., 1988; Tanaka et al., 1989; Johnson et al., 1990; Abe et al., 1991; Scott et al., 1991; Banati et al., 1993; Iverfeldt et al., 1993). In this context, it was conceivable that injury associated with stereotactic injections into the entorhinal cortex could lead to induced synthesis of KPI APP isoforms, species that have an apparent molecular weight of $\sim 140-150 \mathrm{kDa}$ (Weidemann et al., 1989; Sisodia et al., 1993). To address this potentially confounding factor, we compared the electrophoretic mobility and pattern of CT15immunoreactive polypeptides obtained by Western blot analysis of normal uninjured entorhinal cortex or hippocampus with that obtained by immunoprecipitation of radiolabeled APP from rat brain $6 \mathrm{hr}$ after the stereotactic injection of $\left[{ }^{35} \mathrm{~S}\right]$ methionine. These studies revealed that the pattern of steady-state, full-length APP detected by Western blotting (Fig. 3B) is essentially indistinguishable from the pattern of $\left[{ }^{35} \mathrm{~S}\right]$ methionine-labeled polypeptides recovered by immunoprecipitation (Fig. 3A, left). Hence, induction of APP isoforms containing the KPI domain does not occur in these experiments. Finally, we compared the electrophoretic migration of the APP polypeptides expressed at steady state in the hippocampus and entorhinal cortex with human APP-695 or APP-770 polypeptides overexpressed in transiently transfected COS-1 cells (Fig. 3C). Clearly, the immature, newly synthesized form of APP-695 and at least one of the mature forms of COS-1-synthesized APP-695 comigrate with two of the species observed in brain. Although the fully glycosylated APP695 species in brain appears to comigrate with the immature form of APP-770, these latter species would not be expected to undergo axonal transport because they would not have exited the ER. On the other hand, mature APP-770 species, seen on the longer exposure of the autoradiogram in Figure $3 C$, right, do not comigrate with the APP-related polypeptides detected in brain. Previous studies in the PNS clearly showed that a very small fraction of APP subjected to axonal transport was APP751/770 isoforms and that these molecules had acquired their full complement of oligosaccharides (Sisodia et al., 1993).

Our demonstration that fully glycosylated APP but not immature ER forms are the only full-length forms that accumulate in 


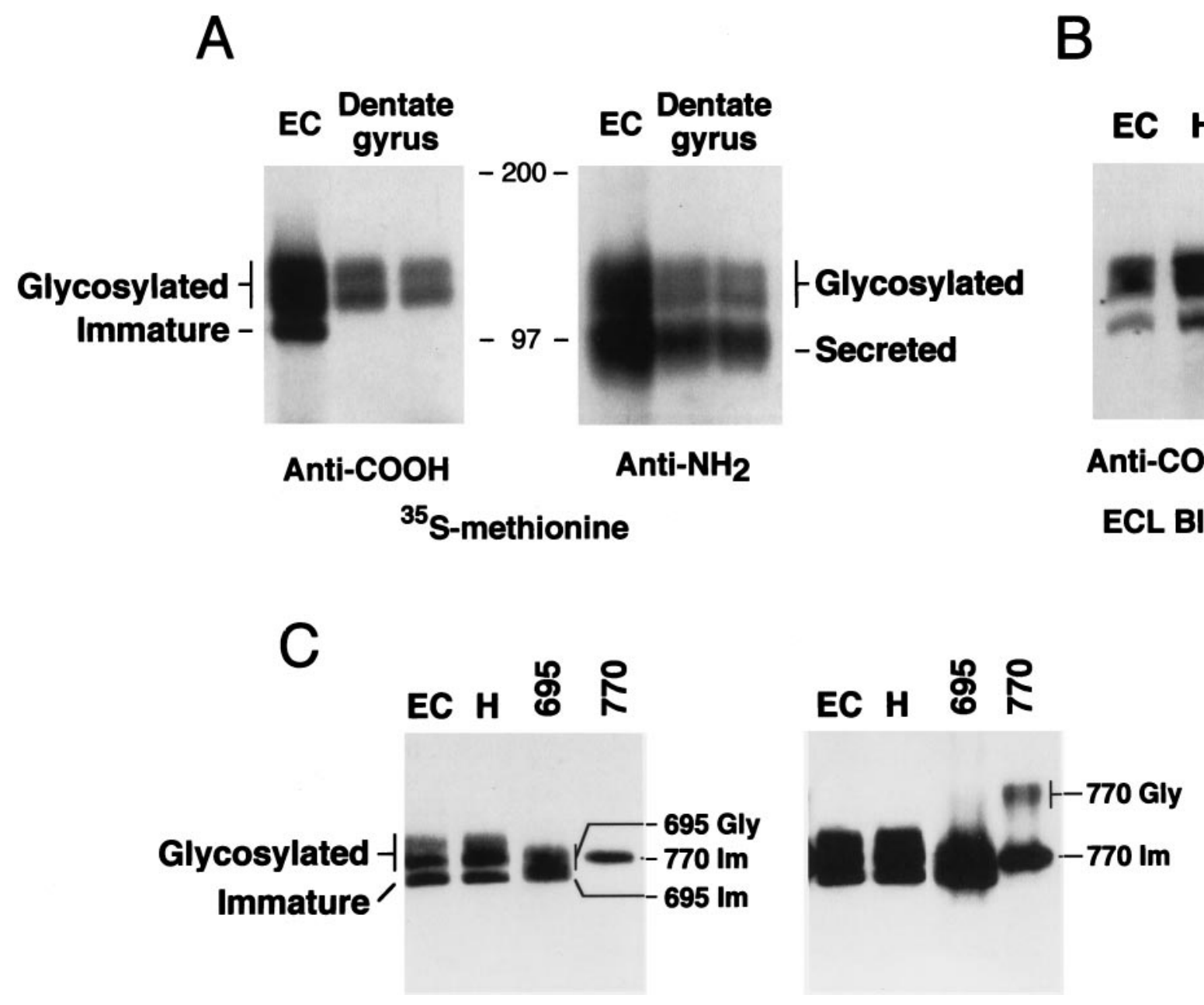

Figure 3. APP undergoes axonal transport in the rat CNS. $A,\left[{ }^{35} \mathrm{~S}\right]$ Methionine was injected into rat entorhinal cortex (EC), and transport was allowed to proceed for $6 \mathrm{hr}$. Subsequently, the entorhinal cortex and the hippocampus were dissected and homogenized, and the labeled APP was analyzed by immunoprecipitation with antibodies reactive with the $\mathrm{C}$ or $\mathrm{N}$ terminal of APP. Full-length APP species that were reactive with anti-C-terminal antibodies and present in the entorhinal cortex but not the hippocampus were identified as incompletely glycosylated (immature) APP. APP species that were reactive with anti-N-terminal antibodies but not anti-C-terminal antibodies were identified as C-terminal-truncated (secreted) APP. Protein molecular weight standards are in kilodaltons. $B$, Full-length APP polypeptides in detergent lysates of uninjured rat entorhinal cortex and hippocampus were visualized by immunoblotting with anti-C-terminal antibodies. $C$, Patterns of full-length APP polypeptides in rat $E C$ and hippocampus $(H)$ are compared with human APP-695 and APP-770 transiently expressed in transfected COS-1 cells; $25 \mu \mathrm{g}$ of detergent-soluble homogenate from $E C$ or $H$ and $5 \mu \mathrm{l}$ of detergent-soluble cell lysate from COS-1 cells were fractionated on $7 \%$ Tris-glycine gels. The right panel is a longer exposure of the left panel and allows visualization of mature APP-770 (770 Gly) Gly, Mature; Im, immature.

the dentate gyrus (Fig. 3A, left) argues that these molecules represent bona fide transported APP. Using an APP N-terminal antibody, RGP3, on the other hand, we observed a pattern of polypeptides very similar to that obtained with CT15 antibody. However, an additional polypeptide of $\sim 100 \mathrm{kDa}$ was also detected with the RGP3 antibody in the hippocampal formation that is also present in the entorhinal cortex; in this latter case, the polypeptide comigrates with immature APP-695 (Fig. 3A, right). The reactivity of this polypeptide with RGP3, but not with CT15, indicates that this molecule corresponds to $\mathrm{C}$-terminal-truncated, soluble APP $\left(\mathrm{APP}^{\mathrm{s}}\right)$. Thus, both full-length and soluble APP forms, synthesized in the entorhinal cortex, can be detected in the hippocampal formation.

\section{Potentially amyloidogenic fragments accumulate at synaptic sites}

Having established that RGP3-immunoreactive APP ${ }^{\mathrm{s}}$ accumulates in the entorhinal cortex and hippocampal formation, we asked whether residual, membrane-bound APP CTFs might also be present in these areas. For these analyses, we used CT15 for immunoprecipitation and fractionated recovered polypeptides on a highly cross-linked, Tris-tricine SDS-PAGE system that effectively resolves low molecular weight polypeptides. We observed five CT15-immunoprecipitable species between $\sim 9-14 \mathrm{kDa}$ in extracts prepared from both brain regions (Fig. 4A, left). These species were also observed when extracts of lysed crude synaptosomal extracts were examined in parallel by immunoblotting (Fig. $4 A$, center), indicating that these fragments accumulate at steady state. Interestingly, the slowest migrating species exhibited retarded mobility relative to the electrophoretic migration of an APP fragment (C100) (that represents the C-terminal 100 amino acids of the protein and contains the entire $\mathrm{A} \beta$ sequence), whereas a second species migrated with mobility similar to that of C100 (Fig. 4A, right).

To verify that the APP CTFs were not artifactually generated 


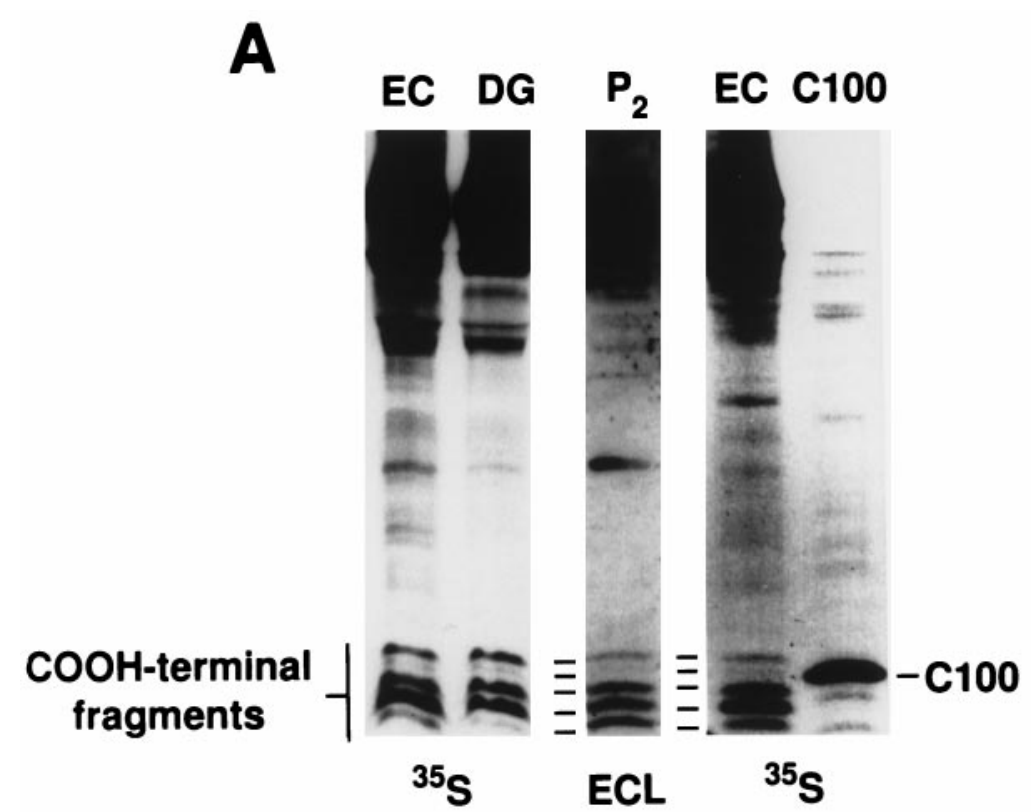

B

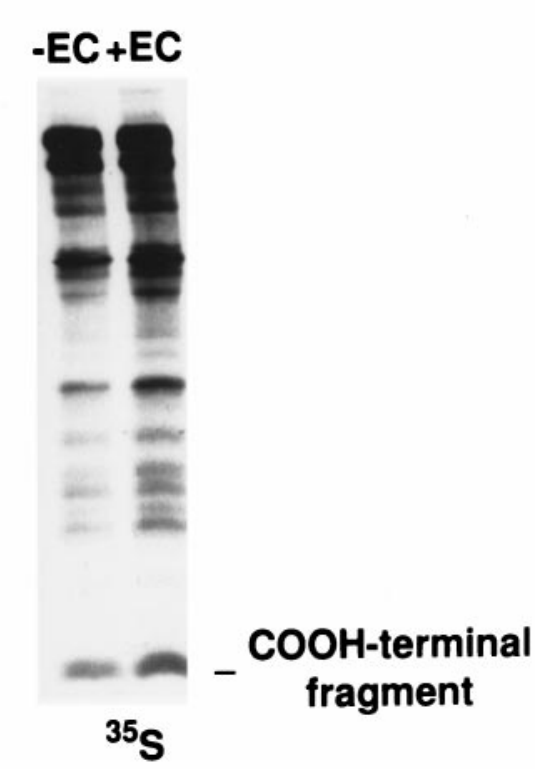

Figure 4. Potentially amyloidogenic CTFs of APP accumulate in the synaptic and/or axonal compartment in the rat CNS. $\left[{ }^{35}\right.$ S]Methionine was injected into rat entorhinal cortex, and transport was allowed to proceed for $6 \mathrm{hr}$. Subsequently, the entorhinal cortex and the hippocampus were dissected and homogenized, and the labeled APP was analyzed by immunoprecipitation with antibodies reactive with the C terminal of APP. The precipitates were fractionated on Tris-tricine gels to resolve the low molecular weight APP-derived species. A, Visualization of APP CTFs. Left, Five C-terminal fragments were identified in the entorhinal cortex and in the hippocampus by immunoprecipitation of ${ }^{35} \mathrm{~S}$-labeled protein. Center, Similar bands were also observed in $E C L$-labeled immunoblots of proteins extracted from crude synaptosomal fractions $(P 2)$. Right, Two of the bands observed in brain tissue had an apparent molecular mass that was the same as or higher than that of C100 extracted from CHO cells, stably expressing C100. DG, Dentate gyrus. $B$, Effects of entorhinal cortex extracts on APP degradation. CHO cells, overexpressing APP ${ }_{770}$, were labeled with [ ${ }^{35}$ S]methionine and lysed. The lysate was divided into two aliquots and incubated in the absence $(-E C)$ or presence $(+E C)$ of extracts of nonlabeled entorhinal cortex. After incubation, the ${ }^{35} \mathrm{~S}$-labeled C-terminal fragments were analyzed from both aliquots on $16 \%$ Tris-glycine gels.

during homogenization or immunoprecipitation, we labeled cultured cells overexpressing human APP-770 with $\left[{ }^{35} \mathrm{~S}\right]$ methionine and then lysed the cells in the absence or presence of extracts of entorhinal cortex. Resulting mixtures were subjected to immunoprecipitation with CT15 and resolved on $16 \%$ Tris-glycine gels. We failed to see any difference in either the pattern or absolute levels of radiolabeled full-length APP770 or the CTFs derived from APP-770 in lysates incubated with cortical extracts as compared with control lysates (Fig. 4B). It is important to note that the CTFs detected in Chinese hamster ovary $(\mathrm{CHO})$ cells appear less complex than do those obtained from brain, and this result simply reflects the fact that low molecular weight polypeptides are poorly resolved in Tris-glycine gels. In any event, these studies argue against artifactual generation of CTFs during lysis or homogenization but instead support the view that the CTFs observed in the entorhinal cortex and hippocampal formation are generated by physiologically relevant processing events found in the living brain.

To establish further the identity of APP CTFs, we subjected detergent lysates of entorhinal cortex or hippocampus to immunoprecipitation analysis with CT15 antibody or with 3134N antibody, specific for epitopes between amino acids 5 and 12 of the $\mathrm{A} \beta$ sequence. Furthermore, and in view of the abundant evidence that serine and threonine residues in the APP cytoplasmic domain are post-translationally modified by phosphate moieties in vivo (Oishi et al., 1997), we treated CT15 or 3134N immune complexes with bacteriophage $\lambda$ protein phosphatase (which removes phosphate groups from serine, threonine, or tyrosine residues) and subjected resulting products to Western blot analysis with CT15 antibody (Fig. 5). These analyses revealed that only the largest of the APP CTFs of $\sim 12$ and $\sim 11 \mathrm{kDa}$ are detected by $3134 \mathrm{~N}$; the largest of these two fragments exhibits accelerated migration after $\lambda$ phosphatase treatment and collapses into the $\sim 11 \mathrm{kDa}$ fragment (Fig. 5A, compare lanes 5, 6). Interestingly, this $\sim 11 \mathrm{kDa}$ fragment exhibits mobility not different than that of the fragment shown earlier (Fig. $4 A$ ) to comigrate with a synthetic CT100 peptide. Our interpretation of these findings is that the largest APP CTF is a phosphorylated form of the $\sim 11 \mathrm{kDa}$, presumably the $\mathrm{CT} 100$ fragment, that contains the entire $\mathrm{A} \beta$ peptide. The mobility of several of the CT15-immunoprecipitable CTFs also shifts after phosphatase treatment (Fig. 5A, lanes 3, 4). For example, and fully consistent with the $3134 \mathrm{~N}$ analysis, the largest $\sim 12 \mathrm{kDa}$ species shifts to $\sim 11 \mathrm{kDa}$. In addition, a CTF of $\sim 10.5 \mathrm{kDa}$ disappears after phosphatase treatment, whereas the levels of the slowest migrating CTFs of $\sim 9.5$ and $\sim 8.5 \mathrm{kDa}$ appear to be enhanced after phosphatase treatment. Our interpretation of these data are summarized in Figure $5 B$. We propose that the $\sim 10.5 \mathrm{kDa}$ CTF is a phosphorylated form of an APP CTF initiating at amino acid 11 of A $\beta(+11 \mathrm{CTF})$, a CTF that has been described previously by Simons et al. (1996); the $\sim 9.5 \mathrm{kDa}$ CTF is a mixture of nonphosphorylated $+11 \mathrm{CTF}$ and a phosphorylated form of an APP CTF generated after cleavage by $\alpha$-secretase between amino acids 16 and 17 of $\mathrm{A} \beta$ ( $\alpha$-CTF); finally, the $\sim 8.5 \mathrm{kDa} \mathrm{CTF}$ is $\alpha$-CTF. These results suggested that some of the $\mathrm{C}$-terminal bands correspond to fragments that encompass all or parts of the $\mathrm{A} \beta$ domain. The demonstration that $\mathrm{A} \beta$-related peptides with the same $\mathrm{N}$ terminals as the CTFs documented here are present in conditioned medium of cultured cells (Seubert et al., 1992; Naslund et al., 1994; Simons et al., 1996; Wang et al., 1996; Xu et al., 1998) strongly reinforces the 


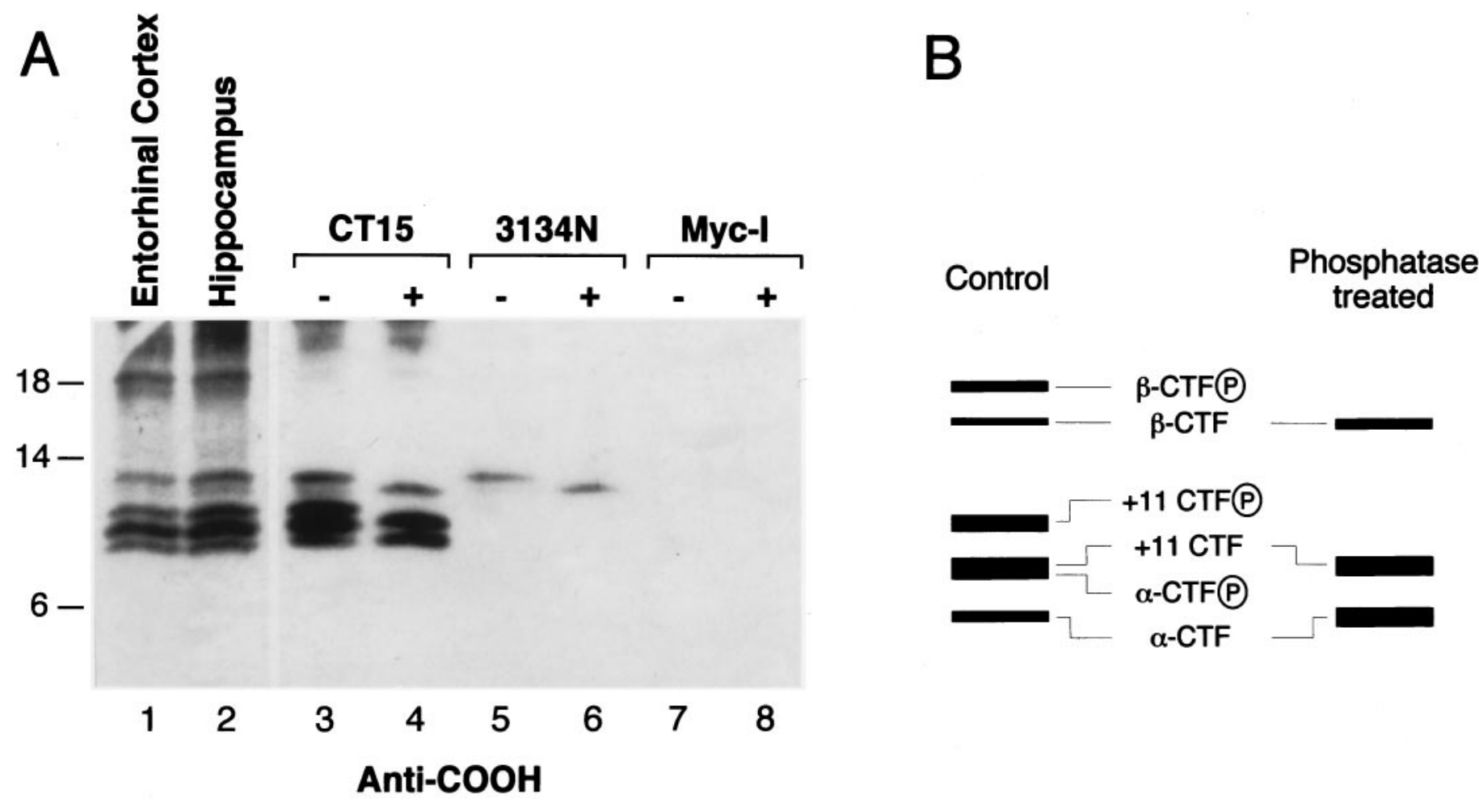

Figure 5. The identity of APP CTFs. A, Detergent lysates were prepared from rat entorhinal cortex and hippocampus. APP CTFs were immunoprecipitated using $C T 15$ or $3134 N$ antibodies, treated with protein phosphatase, and analyzed by immunoblotting with CT15. Lanes 1, 2, Immunoblot analysis of total lysates with CT15. Lanes 3-8, Nontreated $(-)$ and $\lambda$ phosphatase-treated (+) APP immunoprecipitates $(C T 15$ and $3134 N)$ or control immunoprecipitates (anti-Myc, raised against an epitope of the protooncogene c-myc) probed with $C T 15 . B$, The schematic represents our interpretation of the identity of APP CTFs as deduced from the data in $A$ and in earlier biochemical characterization of CTFs (Seubert et al., 1992; Naslund et al., 1994; Simons et al., 1996; Wang et al., 1996; Xu et al., 1998). Circled P, Phosphate.

view that the CTFs are the penultimate precursors of $\mathrm{A} \beta$ and $\mathrm{A} \beta$-related peptides.

\section{APP is transported to synaptic sites}

A major target of the perforant path of layer II/III entorhinal neurons is the dendrites of granule cells in the dentate gyrus. The granule cells give rise to one or several dendrites that branch extensively and are covered with spines. The outer two-thirds of these dendritic fields receive inputs from the entorhinal cortex via the perforant path. To determine whether the full-length and proteolytic-processed APPs that we observed in the hippocampal formation are actually present in the presynaptic terminals of these synapses, we biosynthetically labeled APP by injecting $\left[{ }^{35} \mathrm{~S}\right]$ methionine into the entorhinal cortex of living rats and, after a $6 \mathrm{hr}$ recovery period, microdissected out parts of the dentate gyrus, the entorhinal cortex, and the dorsal hippocampus (which still included some of the granule cell layers of the dentate gyrus) of these animals. The APP-related proteins were recovered from detergent extracts of tissues by immunoprecipitation with RGP3 and CT15 antibodies. As we observed for the entire hippocampal formation, the granule cell region of the dentate gyrus contained labeled (1) full-length, fully glycosylated APP; (2) C-terminaltruncated, soluble APP; and (3) the five C-terminal fragments (Fig. 6). In contrast, the dentate gyrus contained no full-length, immature, unglycosylated APP, again indicating that the APPrelated peptides detected in the terminal fields represent bona fide axonally transported APP species, rather than species derived from local biosynthesis of APP in granule cells after diffusion of injected $\left[{ }^{35} \mathrm{~S}\right]$ methionine.

\section{DISCUSSION}

We have examined APP transport and processing of APP in the rat CNS. The perforant path is a well-characterized neuroanatomical pathway and offers the advantage that the fate of APP, synthesized in the cell bodies of the entorhinal cortex and anterogradely transported to synaptic sites in the dentate gyrus, can be evaluated. We demonstrated that the overwhelming majority of APP synthesized in the entorhinal cortex is $\mathrm{APP}_{695}$. Because the majority of newly synthesized APP in our paradigm is $\mathrm{APP}_{695}$, the task of identifying the APP species was simplified. In the entorhinal cortex, a species of $\sim 110 \mathrm{kDa}$ was reactive with anti-C-terminal antibodies, and this species was absent in the dentate gyrus. This APP species corresponds to APP that has not been fully glycosylated (immature APP). The absence of this immature species in the dentate gyrus indicates that the labeled APP that we observed in the dentate gyrus is derived by fast axonal transport of mature APP that was synthesized in the entorhinal cortex. Thus, we can exclude artifactual results that might arise from diffusion of the $\left[{ }^{35} \mathrm{~S}\right]$ methionine label to the dentate gyrus and the subsequent incorporation of this label into APP synthesized in the granule cells.

We considered the possibility that injury associated with stereotactic injections into the entorhinal cortex might have also induced new synthesis of KPI APP isoforms and that these species might be transported; several studies of experimental lesions and degeneration of the CNS and PNS have shown upregulated expression of KPI-containing APP isoforms (Tanzi et al., 1988; Tanaka et al., 1989; Johnson et al., 1990; Abe et al., 

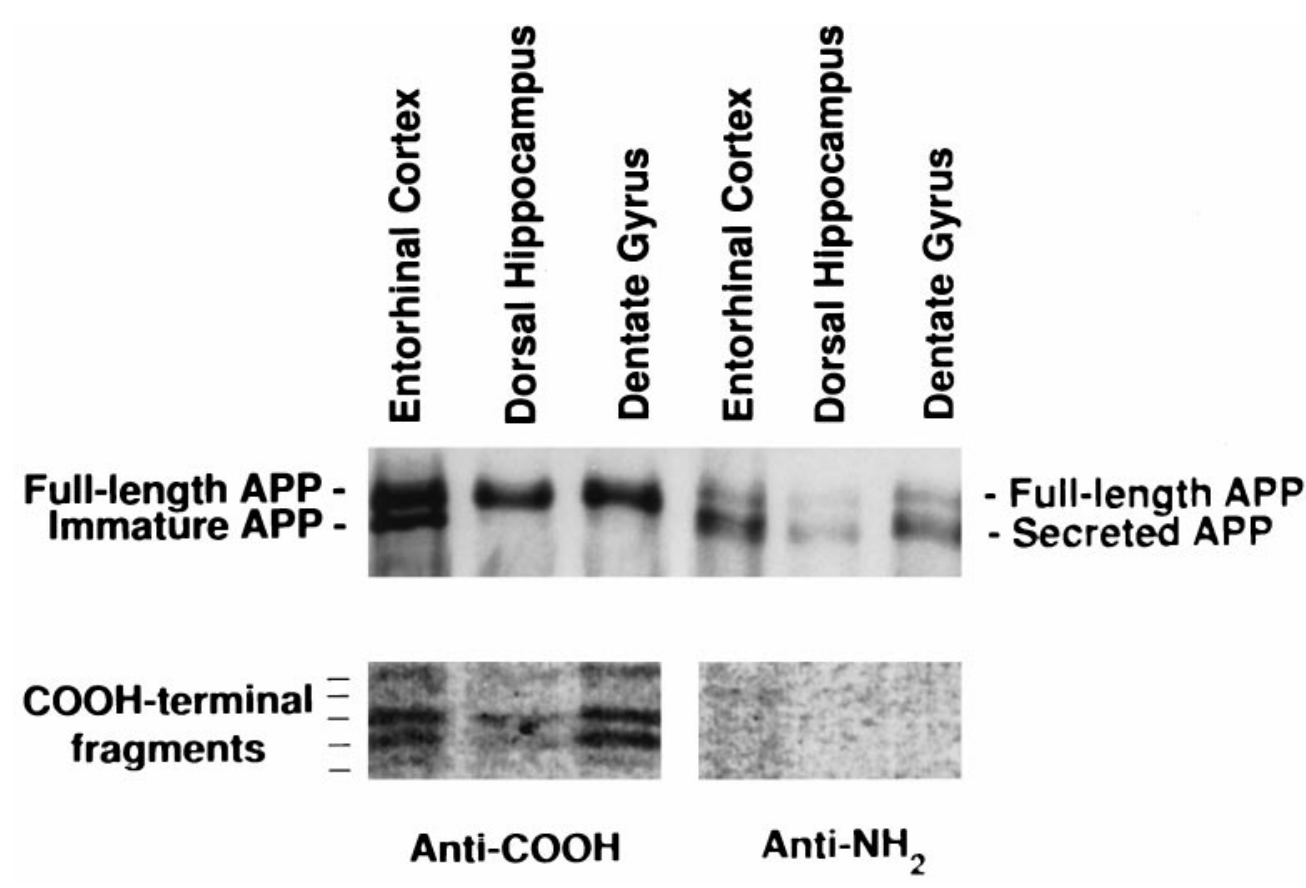

1991; Scott et al., 1991; Banati et al., 1993; Iverfeldt et al., 1993). However, the principal cells in which KPI APP isoforms are induced are astrocytes or microglia (Banati et al., 1993; Iverfeldt et al., 1993). Our demonstration that the steady-state pattern of APP in rat brain is indistinguishable from the pattern obtained after radiolabeling argues against upregulation of novel APP isoforms as a consequence of damage induced by the injection. Moreover, the apparent molecular weight of APP751/770 expressed as a consequence of nerve cell injury is $\sim 145-150 \mathrm{kDa}$ (Sisodia et al., 1993), species that are not detected by Western blotting or radiolabeling. Although it is possible that immunoprecipitation using KPI domain-specific antibodies might help settle this issue, there is an inherent ambiguity in the assay because of the abundant expression of amyloid precursor-like protein-2 (APLP2), an APP homolog, in rodent brain (Slunt et al., 1994); the preponderant brain APLP2 isoform contains a highly homologous KPI domain for which distinguishing antibodies are unavailable. In any event, from an anatomical perspective, the entorhinal cortex in rat is positioned very caudally with respect to the hippocampal formation, and hence, the hippocampus is immune to lesions associated with the needle track. Thus, the only conceivable way that radiolabeled APP would be present in the hippocampus after injection of $\left[{ }^{35} \mathrm{~S}\right]$ methionine into the rat entorhinal cortex is after delivery via fast axonal transport. Moreover, and if one were to argue that the $\sim 110-120 \mathrm{kDa}$ APP-695 polypeptides were synthesized by non-neuronal cells in the entorhinal cortex, it is implausible that these molecules would be subject to axonal transport.

In the dentate gyrus, we observed APP products that appeared to correspond to full-length, fully glycosylated species. The accumulation of full-length APP in synaptosomal preparations using biochemical approaches has been recently reported (Ikin et al., 1996; Marquez-Sterling et al., 1997). It is of interest to note that in these studies, it appeared that full-length APP in the nerve terminals was included in structures associated with the endocytic pathway, particularly in multilamellar organelles and clathrincoated vesicles; APP was fully excluded from small synaptic vesicles. In the dentate gyrus, an APP species of $\sim 105 \mathrm{kDa}$ was
Figure 6. Full-length APP, secreted APP, and C-terminal fragments of APP accumulate in synaptic sites in the dentate gyrus. $\left[{ }^{35}\right.$ S $]$ Methionine was injected into rat entorhinal cortex, and transport was allowed to proceed for 6 hr. Subsequently, the entorhinal cortex and the hippocampus were dissected. The hippocampus was sectioned, and the dentate gyrus was removed. The entorhinal cortex, the dentate gyrus, and the remainder of the hippocampus (dorsal hippocampus) were homogenized, and the labeled APP was analyzed by immunoprecipitation with antibodies reactive with the $\mathrm{C}$ or $\mathrm{N}$ terminal of APP. Recovered immune complexes were resolved on Tris-tricine gels, and the dried gels were exposed for 2 months to x-ray film. APP species were identified as described in the legends to Figures 2 and 3. observed that was reactive with anti-N-terminal antibodies but not with anti-C-terminal antibodies. This species likely represents soluble APP derivatives generated after truncation at, or proximal to, the predominant $\alpha$-secretase cleavage site of APP, analogous to the prominent secreted APP molecule recovered in cell culture medium (Weidemann et al., 1989). For technical reasons, we cannot distinguish whether truncated APP is within the presynaptic terminals or associated with the extracellular space. The presence of the C-terminal-truncated species suggests a physiological role for this product, perhaps as a ligand that can interact with postsynaptic receptors (Furukawa et al., 1996).

In all brain areas examined, we also observed five low molecular weight APP-related species that were immunoreactive with anti-C-terminal antibodies. These bands are likely to correspond to CTFs of APP that remain membrane-associated after proteolytic cleavage within the juxtamembranous, extracellular domain. These CTFs are remarkably similar to the CTFs observed in primary cultures of embryonic rat neurons transiently expressing human APP (Simons et al., 1996). Notably, two of the slowest migrating fragments in rat brain exhibit similar or slightly retarded electrophoretic mobility relative to that of an APP C-terminal fragment (C100) that encompasses the entire cytoplasmic domain of APP, the transmembrane domain, and the entire $\mathrm{A} \beta$ region, and our protein dephosphorylation studies and $\mathrm{A} \beta$-specific antibody immunoblotting studies suggest that the two CTFs are phospho- and dephospho-forms of the same CTF that contain the entire $\mathrm{A} \beta$ peptide sequence. Hence, this derivative may represent the penultimate precursor of $\mathrm{A} \beta$ in the brain, including at synaptic sites. Although the presence of phosphorylated APP CTFs in brain has not been reported previously, these findings are not unexpected because earlier studies have established that in cultured cells and rat brain, the cytoplasmic domain of holo-APP is phosphorylated at Thr654, Ser655, and Thr668 (of APP-695) (Oishi et al., 1997). Interestingly, APP is also subject to ectodomain phosphorylation at Ser198 and Ser206, but these latter studies have only been validated in cultured cells (Walter et al., 1997). The physiological relevance of APP phosphorylation in the ecto- or cytoplasmic domains has not been established. 
The relationship of APP CTFs in brain to Alzheimer's disease pathogenesis merits discussion. Early studies strongly suggested that the CTFs are the penultimate precursors of $\mathrm{A} \beta$ peptides (Simons et al., 1996). This view has gained considerable experimental support. First, cells and transgenic mice expressing the Swedish APP variant secrete high levels of $\mathrm{A} \beta$, coincident with the production of elevated levels of APP CTF with an N terminal at the $\beta$-secretase site (Thinakaran et al., 1996; Lamb et al., 1997; McPhie et al., 1997). The most remarkable finding is that neurons from mice lacking presenilin 1 fail to secrete $A \beta$ and $A \beta$-related peptides, and this is coincident with the accumulation of APP CTFs intracellularly (DeStrooper et al., 1998; Naruse et al., 1998). Are there additional pathogenic properties of APP CTF? Evidence has accumulated that insoluble APP CTFs accumulate in cells that have internalized $\mathrm{A} \beta 1-42$ peptide aggregates (Yang et al., 1995); in this regard, several reports have provided evidence that APP CTFs containing the A $\beta$ domain are toxic both in vitro (Kim and Suh, 1996) and in vivo (Oster-Granite et al., 1996).

Finally, it is important to note that although $\mathrm{A} \beta$-containing C-terminal peptides accumulate at synaptic sites, we have been unsuccessful in detecting radiolabeled $\mathrm{A} \beta$ in this perforant path axonal transport paradigm, even after injections of $\sim 3 \mathrm{mCi}$ of $\left[{ }^{35} \mathrm{~S}\right]$ methionine. Whether this failure to detect radiolabeled $\mathrm{A} \beta$ peptides reflects the high turnover, or inefficient production, of $\mathrm{A} \beta$ peptides in the rodent $\mathrm{CNS}$ is not presently known. In view of recent sandwich ELISA measurements of $A \beta$ in mouse brain that reveal that these peptides accumulate to only $\sim 2-3$ pmol per gram of wet weight of tissue (Duff et al., 1996), it is not particularly surprising that our efforts to detect biosynthetically labeled $\mathrm{A} \beta$ have been unsuccessful.

In summary, we observed that full-length APP, C-terminaltruncated APP, and C-terminal fragments of APP accumulate at synaptic sites in the CNS. At present, it is not clear whether the cleaved APP products are generated at the nerve terminal and/or whether cleavage occurs before, or during, transport. Although earlier studies have indicated that full-length APP is present in the nerve terminal and is found within multilamellar bodies and clathrin-coated vesicles, the disposition of C-terminal-truncated (soluble) APP within the extrasynaptic space and/or in organelles within the nerve terminal is not known. Clarification of these issues will further our understanding of the function of APP, the cellular sites of APP cleavage, and $\mathrm{A} \beta$ formation in the CNS.

\section{REFERENCES}

Abe K, Tanzi RE, Kogure K (1991) Selective induction of Kunitz-type protease inhibitor domain-containing amyloid precursor protein mRNA after persistent focal ischemia in rat cerebral cortex. Neurosci Lett 124:172-174.

Arnold SE, Hyman BT, Flory J, Damasio AR, Van Hoesen GW (1991) The topographical and neuroanatomical distribution of neurofibrillary tangles and neuritic plaques in the cerebral cortex of patients with Alzheimer's disease. Cereb Cortex 1:103-116.

Banati RB, Gehrmann J, Czech C, Monning U, Jones LL, Konig G, Beyreuther K, Kreutzberg GW (1993) Early and rapid de novo synthesis of Alzheimer $\beta$ A4-amyloid precursor protein (APP) in activated microglia. Glia 9:199-210.

Beyreuther K, Masters CL (1991) Amyloid precursor protein (APP) and $\beta A 4$ amyloid in the etiology of Alzheimer's disease: precursor-product relationships in the derangement of neuronal function. Brain Pathol 1:241-251.

Braak H, Braak E (1994) Pathology of Alzheimer's disease. In: Neurodegenerative diseases (Calne DB, ed), pp 585-613. Philadelphia: Saunders.

Desdouits F, Buxbaum JD, Desdouits-Magnen J, Nairn AC, Greengard P
(1996) Amyloid peptide formation in cell-free preparations: regulation by protein kinase $\mathrm{C}$, calmodulin, and calcineurin. J Biol Chem 271:24670-24674.

De Strooper B, Saftig P, Craessaerts K, Vanderstichele H, Guhde G, Annaert W, Von Figura K, Van Leuven F (1998) Deficiency of presenilin-1 inhibits the normal cleavage of amyloid precursor protein. Nature 391:387-390.

Duff K, Eckman C, Zehr C, Yu X, Prada CM, Perez-tur J, Hutton M, Buee L, Harigaya Y, Yager D, Morgan D, Gordon MN, Holcomb L, Refolo L, Zenk B, Hardy J, Younkin S (1996) Increased amyloidbeta42(43) in brains of mice expressing mutant presenilin 1 . Nature 383:710-713.

Furukawa K, Barger SW, Blalock EM, Mattson MP (1996) Activation of $\mathrm{K}+$ channels and suppression of neuronal activity by secreted betaamyloid-precursor protein. Nature 379:74-78.

Glenner GG, Wong CW (1984) Alzheimer's disease: initial report of the purification and characterization of a novel cerebrovascular amyloid protein. Biochem Biophys Res Commun 120:885-890.

Golde TE, Estus S, Usiak M, Younkin LH, Younkin SG (1990) Expression of beta amyloid protein precursor mRNAs: recognition of a novel alternatively spliced form and quantitation in Alzheimer's disease using PCR. Neuron 4:253-267.

Ikin AF, Annaert WG, Takei K, De Camilli P, Jahn R, Greengard P, Buxbaum JD (1996) Alzheimer amyloid protein precursor is localized in nerve terminal preparations to Rab5-containing vesicular organelles distinct from those implicated in the synaptic vesicle pathway. J Biol Chem 271:31783-31786.

Iverfeldt K, Walaas SI, Greengard P (1993) Altered processing of Alzheimer amyloid precursor protein in response to neuronal degeneration. Proc Natl Acad Sci USA 90:4146-4150.

Johnson SA, McNeill T, Cordell B, Finch CE (1990) Regulation of neuronal APP-751/APP-695 mRNA ratio and neuritic plaque density in Alzheimer's disease. Science 248:854-855.

Kang J, Lemaire HG, Unterbeck A, Salbaum JM, Masters CL, Grzeschik KH, Multhaup G, Beyreuther K, Muller-Hill B (1987) The precursor of Alzheimer's disease amyloid A4 protein resembles a cell-surface receptor. Nature 325:733-736.

Kim SH, Suh YH (1996) Neurotoxicity of a carboxyl-terminal fragment of the Alzheimer's amyloid precursor protein. J Neurochem 67:1172-1182.

Kitaguchi N, Takahashi Y, Tokushima Y, Shiojiri S, Ito H (1988) Novel precursor of Alzheimer's disease amyloid protein shows protease inhibitory activity. Nature 331:530-532.

König G, Monning U, Czech C, Prior R, Banati R, Schreiter-Gasser U, Bauer J, Masters CL, Beyreuther K (1992) Identification and differential expression of a novel alternative splice isoform of the $\beta \mathrm{A} 4$ amyloid precursor protein (APP) mRNA in leukocytes and brain microglial cells. J Biol Chem 267:10804-10809.

Koo EH, Squazzo SL (1994) Evidence that production and release of amyloid beta-protein involves the endocytic pathway. J Biol Chem 269:17386-17389.

Koo EH, Sisodia SS, Archer DR, Martin LJ, Weidemann A, Beyreuther K, Fischer P, Masters CL, Price DL (1990) Precursor of amyloid protein in Alzheimer disease undergoes fast anterograde axonal transport. Proc Natl Acad Sci USA 87:1561-1565.

Lamb BT, Call LM, Slunt HH, Bardel KA, Lawler AM, Eckman CB, Younkin SG, Holtz G, Wagner SL, Price DL, Sisodia SS, Gearhart JD (1997) Altered metabolism of familial Alzheimer's disease-linked amyloid precursor protein variants in yeast artificial chromosome transgenic mice. Hum Mol Genet 6:1535-1541.

Marquez-Sterling NR, Lo ACY, Sisodia SS, Koo EH (1997) Trafficking of cell-surface beta-amyloid precursor protein: evidence that a sorting intermediate participates in synaptic vesicle recycling. J Neurosci 17:140-151.

McPhie DL, Lee RKK, Eckman CB, Olstein DH, Durham SP, Yager D, Younkin SG, Wurtman RJ, Neve RL (1997) Neuronal expression of $\beta$-amyloid precursor protein Alzheimer mutations causes intracellular accumulation of a $\mathrm{C}$-terminal fragment containing both the amyloid $\beta$ and cytoplasmic domains. J Biol Chem 272:24743-24746.

Morin PJ, Abraham CR, Amaratunga A, Johnson RJ, Huber G, Sandell JH, Fine RE (1993) Amyloid precursor protein is synthesized by retinal ganglion cells, rapidly transported to the optic nerve plasma membrane and nerve terminals, and metabolized. J Neurochem 61:464-473.

Naruse S, Thinakaran G, Luo J-J, Kusiak JW, Tomita T, Iwatsubo T, Qian X, Ginty DD, Price DL, Borchelt DR, Wong PC, Sisodia SS 
(1998) Effects of PS1 deficiency on membrane protein trafficking in neurons. Neuron, in press.

Naslund J, Schierhorn A, Hellman U, Lannfelt L, Roses AD, Tjernberg LO, Silberring J, Gandy SE, Winblad B, Greengard P, Nordstedt C, Terenius L (1994) Relative abundance of Alzheimer A beta amyloid peptide variants in Alzheimer disease and normal aging. Proc Natl Acad Sci USA 91:8378-8382.

Neve RL, Finch EA, Dawes LR (1988) Expression of the Alzheimer amyloid precursor gene transcript in the human brain. Neuron 1:669-677.

Nordstedt C, Caporaso GL, Thyberg J, Gandy SE, Greengard P (1993) Identification of the Alzheimer $\beta / \mathrm{A} 4$ amyloid precursor protein in clathrin-coated vesicles purified from PC12 cells. J Biol Chem 268:608-612.

Ohyagi T, Takahashi K, Kamegai M, Tabira T (1990) Developmental and differential expression of beta amyloid protein precursor mRNAs in mouse brain. Biochem Biophys Res Commun 167:54-60.

Oishi M, Nairn AC, Czernik AJ, Lim GS, Isohara T, Gandy SE, Greengard P, Suzuki T (1997) The cytoplasmic domain of Alzheimer's amyloid precursor protein is phosphorylated at Thr654, Ser655, and Thr668 in adult rat brain and cultured cells. Mol Med 3:111-123.

Oster-Granite ML, McPhie DL, Greenan J, Neve RL (1996) Agedependent neuronal and synaptic degeneration in mice transgenic for the $\mathrm{C}$ terminus of the amyloid precursor protein. J Neurosci 16:6732-6741.

Perry G, Lipphardt S, Kancherla M, Gambetti P, Maggiora L, Lobl T, Mulvihill P, Mijares M, Sharma S, Cornette J, Greenberg B (1988) A new A4 amyloid mRNA contains a domain homologous to serine proteinase inhibitors. Nature 331:525-532.

Ponte P, Gonzalez-DeWhitt P, Schilling J, Miller J, Hsu D, Greenberg B, Davis K, Wallace W, Lieberburg I, Fuller F (1988) A new A4 amyloid mRNA contains a domain homologous to serine proteinase inhibitors. Nature 331:525-527.

Price DL, Kawas CH, Sisodia SS (1996) Aging of the brain and dementia of the Alzheimer's type. In: Principles of neural science (Kandel ER, Schwartz JH, Jessell TM, eds). New York: Elsevier.

Sandbrink R, Masters CL, Beyreuther K (1994) $\beta$ A4-Amyloid protein precursor mRNA isoforms without exon 15 are ubiquitously expressed in rat tissues including brain, but not in neurons. J Biol Chem 269:1510-1517.

Scott JN, Parhad IM, Clark AW (1991) $\beta$-Amyloid precursor protein gene is differentially expressed in axotomized sensory and motor systems. Mol Brain Res 10:315-325.

Selkoe DJ (1996) Amyloid beta-protein and the genetics of Alzheimer's disease. J Biol Chem 271:18295-18298.

Seubert P, Vigo-Pelfrey C, Esch F, Lee M, Dovey H, Davis D, Sinha S, Schlossmacher M, Whaley J, Swindlehurst C, McCormack R, Wolfert R, Selkoe D, Lieberburg I, Schenk D (1992) Isolation and quantification of soluble Alzheimer's beta-peptide from biological fluids. Nature 359:325-327.

Simons M, de Strooper B, Multhaup G, Tienari PJ, Dotti CG, Beyreuther K (1996) Amyloidogenic processing of the human amyloid precursor protein in primary cultures of rat hippocampal neurons. J Neurosci 16:899-908.
Sisodia SS, Koo EH, Beyreuther K, Unterbeck A, Price DL (1990) Evidence that $\beta$-amyloid protein in Alzheimer's disease is not derived by normal processing. Science 248:492-495.

Sisodia SS, Koo EH, Hoffman PN, Perry G, Price DL (1993) Identification and transport of full-length amyloid precursor proteins in rat peripheral nervous system. J Neurosci 13:3136-3142.

Slunt HH, Thinakaran G, Von Koch C, Lo ACY, Tanzi RE, Sisodia SS (1994) Expression of a ubiquitous, cross-reactive homologue of the mouse $\beta$-amyloid precursor protein (APP). J Biol Chem 269:2637-2644.

Squire LR (1994) Memory and forgetting: long-term and gradual changes in memory storage. Int Rev Neurobiol 37:243-269.

Tanaka S, Shiojiri S, Takahashi Y, Kitaguchi N, Ito H, Kameyama M, Kimura J, Nakamura S, Uead K (1989) Tissue expression of three types of $\beta$-protein precursor mRNA: enhancement of protease inhibitor-harboring types in Alzheimer's disease brain. Biochem Biophys Res Commun 165:1406-1414.

Tanzi RE, McClatchey AI, Lamperti ED, Villa-Komaroff L, Gusella JF, Neve RL (1988) Protease inhibitor domain encoded by an amyloid protein precursor mRNA associated with Alzheimer's disease. Nature 331:528-530.

Thinakaran G, Teplow DB, Siman R, Greenberg B, Sisodia SS (1996) Metabolism of the "Swedish" amyloid precursor protein variant in neuro2a (N2a) cells. J Biol Chem 271:9390-9397.

von Koch CS, Zheng H, Chen H, Trumbauer M, Thinakaran G, Van der Ploeg LHT, Price DL, Sisodia SS (1997) Generation of APLP2 KO mice and early postnatal lethality in APLP2/APP double KO mice. Neurobiol Aging 18:661-669.

Walter J, Capell A, Hung AY, Langen H, Schnölzer M, Thinakaran G, Sisodia SS, Selkoe DJ, Haass C (1997) Ectodomain phosphorylation of $\beta$-amyloid precursor protein at two distinct cellular locations. J Biol Chem 272:1896-1903.

Wang R, Sweeney D, Gandy SE, Sisodia SS (1996) The profile of soluble amyloid beta protein in cultured cell media. Detection and quantification of amyloid beta protein and variants by immunoprecipitation-mass spectrometry. J Biol Chem 271:31894-31902.

Weidemann A, Konig G, Bunke D, Fischer P, Salbaum JM, Masters CL, Beyreuther K (1989) Identification, biogenesis, and localization of precursors of Alzheimer's disease A4 amyloid protein. Cell 57:115-126.

Xu H, Gouras GK, Greenfield JP, Vincent B, Naslund J, Mazzarelli L, Fried G, Jovanovic JN, Seeger M, Relkin NR, Liao F, Checler F, Buxbaum JD, Chait BT, Thinakaran G, Sisodia SS, Wang R, Greengard P, Gandy S (1998) Estrogen reduces neuronal generation of Alzheimer beta-amyloid peptides. Nat Med 4:447-451.

Yang AJ, Knauer M, Burdick DA, Glabe C (1995) Intracellular A1-42 aggregates stimulate the accumulation of stable, insoluble amyloidogenic fragments of the amyloid precursor protein in transfected cells. J Biol Chem 270:14786-14792.

Zheng H, Jiang M-H, Trumbauer ME, Sirinathsinghji DJS, Hopkins R, Smith DW, Heavens RP, Dawson GR, Boyce S, Conner MW, Stevens KA, Slunt HH, Sisodia SS, Chen HY, Van der Ploeg LHT (1995) $\beta$-Amyloid precursor protein-deficient mice show reactive gliosis and decreased locomotor activity. Cell 81:525-531. 